African Crop Science Journal, Vol. 9. No. 4, pp. 667-676, 2001

Printed in Uganda. All rights reserved

ISSN 1021-9730/2001 \$4.00

C2001, African Crop Science Society

\title{
ROTATIONAL EFFECTS OF GRAIN LEGUMES ON MAIZE PERFORMANCE IN THE RIFT VALLEY HIGHLANDS OF KENYA
}

\author{
E.K. CHERUIYOT, L.M. MUMERA, L.N. NAKHONE ${ }^{1}$ and S.M. MWONGA ${ }^{1}$ \\ Egerton University, Department of Agronomy, P.O. Box 536, Njoro, Kenya \\ ${ }^{1}$ Egerton University, Department of Soil Science, P.O. Box 536, Njoro, Kenya
}

(Received 27 October, 2000; accepted 25 July, 2001)

\begin{abstract}
High fertiliser costs and declining soil fertility areamong the key factors contributing to low crop yields in Kenya. The contribution of five legumes grown in the short-rains season to soil nitrogen status and performance of a succeeding maize (Zea mays L.) was studied in an experiment at Njoro and Rongai within the Rift Valley Highlands of Kenya, from 1997 to 1999. Treatments included a weedy fallow, five grain legumes and maize (H513) grown during short-rains season followed by maize in the April-August long-rains season. The legumes were chickpea (Cicer arietinum L.), field bean (Phaseolus vulgaris L.), soybean [Glycine max (L.) Merril], garden pea (Pisum sativum L.), dolichos [Lablab purpureus (L.) Sweet]. The crop residues and vegetation of the weedy fallow were incorporated in the soil during seedbed preparation for the long rains season. The maize test crop was supplied with three levels of nitrogen, 0,30 , and $60 \mathrm{~kg} \mathrm{ha}^{-1}$ as main factor whilst fallow management options were allocated as sub-factors in a split-plot treatment arrangement of a randomised complete block design replicated three times. Results show improved soil $\mathrm{N}$ status following legumes, with dolichos giving highest available $\mathrm{N}$. Grain yield in maize succeeding legumes was $24-68 \%$ higher than maize succeeding weed fallow. In the absence of $\mathrm{N}$ fertiliser input, maize succeeding dolichos gave $20-40 \%$ higher yield than maize after weed fallow treated with recommended $60 \mathrm{~kg} \mathrm{~N}^{-1}$ fertiliser rate. The study has demonstrated that the use of grain legumes, particularly dolichos in rotation with maize, is a viable and preferable option to weedy fallows and maize-maize sequences.
\end{abstract}

Key Words: Chickpea, crop rotation, dolichos, fallow, field bean, garden pea, maize, soybean

\section{RÉSUMÉ}

Les coûts très élevés des engrais et le déclin de la fertilité du sol sont parmi les facteurs clés qui contribuent au faible rendement des cultures au Kenya. La contribution de cinq légumineuses cultivées durant la petite saison de pluie au status de l'azote du sol et la performance du maïs suivant (Zea mays L.) a été étudiée dans un essai à Njoro et Rongai dans les hautes Terres du Rift Valley du Kenya, de 1997 à 1999. Les traitements comprenaient une jachère sarclée, cinq légumineuses à graines et le maïs (H513) cultivés pendant la petite saison de pluie suivie par le maïs durant la grande saison pluvieuse d' avril-Août .Les légumineuses étaient le pois chiche (Cicer arietinum L.), le haricot (Phaseolus vulgaris L.), le soya \{Glycine max (L.), Merril\}, le petit pois (Pisum sativum L.), le lablab \{Lablab purpureus (L.) Sweet\}. Des residues des cultures et la végétation de la jachère étaient incorporées au sol pendant la préparation du semis pour de longues saisons pluvieuses. Le maïs test a été fourni avec trois niveaux d'azote, 0,30 et $60 \mathrm{~kg} \mathrm{ha}^{-1}$ comme facteur principal alors que les options de gestions de la jachère étaient des sous-facteurs dans un arrangement de traitement en split-plot des blocks complètement rendomisés avec trois répétitions. Des résultats ont montré le status de l'azote amélioré après des légumineuses, avec le lablab donnant de l'azote disponible très élevé. Le rendement grain du maïs suivant les légumineuses était 24-68\% plus élevé que le maïs suivant la jachère sarclée. En l'absence des intrants d'engrais azoté, le maïs suivant le lablab 
a donne $20-40 \%$ de rendement supérieur à celui du maïs après la jachère sarclée traités avec le taux recommandé de $60 \mathrm{~kg} \mathrm{~N} \mathrm{ha}{ }^{-1}$. L'étude a montré que l'utilisation des légumineuses, en particulier le lablab en rotation avec le maïs, est une option viable et préferable à la jachère sarclée et à la séquence maïs- maïs.

Mots Clés: Pois chiche, rotation des cultures, lablab, haricot, petit pois, maïs, soya

\section{INTRODUCTION}

Maize (Zea mays L.) is a primary food crop in Kenya and is cultivated country wide. Annual production is estimated to be 2.7 million tonnes which is slightly less than consumption (KARI and MIAC, 1993). Besides frequent unfavourable weather conditions, low input use has constrained maize production (Muriuki, 1998). Kenya's population is projected at 36 million in the year 2010, up from the current 27 million. Per capita arable land has declined over the years from 0.23 to 0.15 hectares in 1981 and 1996 respectively (World Bank, 1998) and increased productivity is therefore essential (KARI, 1992).

Maize yield is often constrained by inadequate nutrient supply as little fertiliser is used due to high costs. Nitrogen can be added to the soil through biological $\mathrm{N}$ fixation by legumes that are less expensive, and more readily available to farmers than inorganic fertilisers. Increased maize yield subsequent to legume production is attributed to improved $\mathrm{N}$ supply following mineralisation of legume plant residues (Onim etal., 1990; Kwesiga and Coe, 1994; Wortmann et al., 1994; Peoples et al., 1995; Oike et al., 1998).

The Kenya Highlands have a bi-modal rainfall pattern with the long rains $(300-600 \mathrm{~mm})$ in April-August and the short rains $(250-400 \mathrm{~mm})$ in October-December (Jaetzold and Schmidt, 1983). Most crops are produced during the long-rains season and much land is fallowed during the short-rains season due to low and erratic rainfall. It may be feasible to produce suitably adapted legumes during the shcrt rains to produce manure for the subsequent crop. It has been reported (Tanner et al., 1994) that traditional short fallows in Ethiopia were managed with legumes that improved grain yields of succeeding cereals. Adaptation of some legumes to the semi-dry fallow gapindicates that legumes can be integrated in cereal production with positive yield results (Mwandemele, unpublished data; Rheenen et al.,
1991; Guto, 1997; Onwonga, 1997). However, more information is needed on the potential of producing legumes during the short rains and on their effects on subsequent cereal crops. Such legumes must tolerate water deficits and produce crop residues of adequate $\mathrm{C}: \mathrm{N}$ ratio to decompose rapidly and supply nutrients to the crops in the subsequent season. The study tested two hypotheses: that the growing of legumes during the short rains season in the Kenya Highlands increases grain yield of a subsequent maize crop and that this yield increase is associated with improved soil $\mathrm{N}$ contributed differentially by the legumes.

\section{MATERIALS AND METHODS}

Site description. The study was conducted in the central Rift Valley region of Kenya, at Egerton University near Njoro $\left(0^{\circ} 23^{\prime} S\right.$ and $\left.35^{\circ} 35^{\prime} \mathrm{E}\right)$ and on a farmer's field at Mangu in Rongai $\left(0^{\circ} 10^{\prime} \mathrm{S}\right.$ and $36^{\circ} 01^{\prime} \mathrm{E}$ ), both within Nakuru District. The sites are in agriculturally high potential zone III(6) and III(5) respectively, within the Kenya Highlands (Jaetzold and Schmidt, 1983) and are about $30 \mathrm{~km}$ apart. Mangu is at an altitude of 1945 $\mathrm{m}$ above sea level and receives annual rainfall of about $900 \mathrm{~mm}$ with a mean annual temperature of $16-18^{\circ} \mathrm{C}$. The soils are well drained sandy clay loams, classified as Vitric Andosols. Egerton University is at $2250 \mathrm{~m}$ above sea level and receives annual precipitation of about $1000 \mathrm{~mm}$ and has a mean annual temperature range of 14$16^{\circ} \mathrm{C}$. The soils are well drained dark reddish clays, classified as Mollic Andosols.

Experimental design and sampling procedures. Twenty one treatments were arranged as a splitplot in a randomised complete block design (RCBD) replicated three times. Three levels of $\mathrm{N}$ fertiliser $\left(0,30\right.$, and $\left.60 \mathrm{~kg} \mathrm{~N}^{\mathrm{N}} \mathrm{a}^{-1}\right)$, applied as Calcium Ammonium Nitrate, were assigned to whole plots measuring $4 \times 21 \mathrm{~m}$. The nitrogen was 
applied during the long rains to the subsequent maize crop at the V6 growth stage (Ritchie et al. 1986). The sub-plots measured $4 \times 3 \mathrm{~m}$ and the treatments consisted of maize (Hybrid H513), a natural fallow and five grain legumes namely: chickpea (Cicer arietinum L.), field bean (Phaseolus vulgaris L.), soybean (Glycine max (L.) Merril), garden pea (Pisum sativum L.) and dolichos (Lablab purpureus (L.) Sweet). These sub-factor treatments were applied during the short-rains season of October-December in 1997 and then again in 1998.

Land was tilled with hand hoes for all treatments except the natural fallow which was left untilled. Fallow management crops (FM) were sown in October, at the recommended spacing; chickpea $30 \times 10 \mathrm{~cm}$, field bean $50 \times 20 \mathrm{~cm}$, soybean $45 \times 15$ $\mathrm{cm}$, garden pea $45 \times 15 \mathrm{~cm}$, dolichos $60 \times 30 \mathrm{~cm}$ and maize $75 \times 30 \mathrm{~cm}$. All legume seeds were inoculated with their specific strains of rhizobia prior to sowing in the first season only and sown without inoculation in the subsequent seasons. Inorganic$P$ was applied as basal treatment at the rate of 60 $\mathrm{kg} \mathrm{P}_{2} \mathrm{O}_{5} \mathrm{ha}^{-1}$ in Triple Superphosphate (TSP), $\mathrm{Ca}\left(\mathrm{H}_{2} \mathrm{PO}_{4}\right)_{2} \mathrm{H}_{2} \mathrm{O}$ as recommended (KARI, 1997). Inorganic $\mathrm{N}$ was not applied to any crop during the short rains season, as most legumes were assumed capable of fixing their own nitrogen from the atmosphere (Marschner, 1995)

Data were collected from each subplot and included the following response variables; stand count, nodule count, nodule dry weight, above ground biomass, vegetative tissue $\mathbf{N}$ content; and seed production. Harvesting of the crops which seeded was done between January and February the following year depending on when each crop matured. The grains were taken while the rest of the vegetative material was left in the field for subsequent incorporation into the soil during land preparation for the long rains season. Three legumes in each plot were sampled by consistently picking the $6^{\text {th }}$ plant from each of the three middle rows in each plot except for fallow and maize plots. This was done at the onset of flowering, approximately 80-85 days after emergence for most species. The nodules were dried at $65^{\circ} \mathrm{C}$ for 48 hours and the dry weights taken. To determine the DM , three plants were randomly sampled in each experimental unit except in fallow plots where a one meter quadrant was used and above ground vegetation taken. The sampling was done to coincide with R3 growth stage, when most plants were expected to be at the peak of dry matter accumulation (Ritchie, et al. 1986). The plants were dried at $65^{\circ} \mathrm{C}$ to constant weight and the dry weight measured. The dry samples were milled and stored for organic carbon and tissue- $\mathrm{N}$ analysis.

The seedbed for maize test crop was prepared in March for all treatments. Maize seed (Hybrid H513) was sown at the onset of long rains in midApril in 1998 at a spacing of $75 \times 30 \mathrm{~cm}$. A blanket application of phosphorus at $60 \mathrm{~kg} \mathrm{P}_{2} \mathrm{O}_{5}$ ha $^{-1}$ was provided as TSP. Other crop management practices were done as recommended. Maize was harvested in October 1998 and the second cycle of the experiment repeated in 1999 in the same plots.

Soil samples were taken six weeks after fallow residue incorporation to coincide with estimated peak mineralisation of legume residues (Palm, 1995; Handayonto et al., 1992), at $0-15 \mathrm{~cm}$ and $15-30 \mathrm{~cm}$ depth from each plot and refrigerated at $4^{\circ} \mathrm{C}$, pending inorganic $\mathrm{N}$ analysis.

Maize sampling for DM determination was done at V6 and R2 growth stages as described by Ritchie et al. (1986). Three plants were sampled at the crown level in each plot. The $4^{\text {th }}$ and $6^{\text {th }}$ plants in the second row and $a 5^{\text {th }}$ in third row were picked for the V6 and the next plants in the same rows for the R2 sampling, respectivey. At each sampling the plant specimens were dried at $65^{\circ} \mathrm{C}$ for a minimum of 48 hours to constant weight. During vegetative development three plants were randomly selected in each plot and used to monitor Leaf Area Index (Norman and Campbell, 1989). At physiological maturity whole plants from the two middle rows were taken and separated into cobs and vegetative tissue, oven dried at $85^{\circ} \mathrm{C}$ to constant weight, and then shelled for grain yield determination and milled for tissue $\mathrm{N}$ analysis.

\section{Plant tissue-N, organic carbon, and Soil} inorganic $\mathbf{N}$ analysis. To determine total $N$ in tissues, plant samples were digested with one tablet of 'Kjeltabs' (containing $3.5 \mathrm{~g} \mathrm{~K}_{2} \mathrm{SO}_{4}$ and $400 \mathrm{mg} \mathrm{CuSO}_{4}$ ) and $5 \mathrm{ml}$ of $\mathrm{H}_{2} \mathrm{SO}_{4}$, in a Tecator 1015 digester at $360^{\circ} \mathrm{C}$ for two hours. After cooling, each diggested sample was dissolved in 
$100 \mathrm{ml}$ distilled water and a $10 \mathrm{ml}$ aliquot taken for distillation (Page et al., 1982; Okalebo et al., 1993).

Inorganic $\mathrm{N}\left(\mathrm{NH}_{4}^{+}+\mathrm{NO}_{3}{ }^{-}\right)$was determined by extracting $8 \mathrm{~g}$ from soil of known moiture content with $80 \mathrm{ml} 2 \mathrm{M} \mathrm{KCl}$ for 1 hour and distilling a 10 $\mathrm{ml}$ aliquot with Magnesium oxide and Dervardas alloy. The distillate was collected over $5 \mathrm{ml}$ boric acid and titrated with $0.002 \mathrm{~N} \mathrm{H}_{2} \mathrm{SO}_{4}$ (Page et al., 1982; Okalebo et al., 1993).

Organic carbon of the plant tissue was determined by the Walkley-Black wet oxidation method and the C:N ratio for each sample calculated by dividing the carbon content with the corresponding $\mathrm{N}$ content (Okalebo et al., 1993).

Data analysis. Data were subjected to analysis of variance using the General Linear Model (GLM) and the means separated by Duncan's Multiple Range Test (DMRT) on a SAS software (SAS 1996; Steel et al 1997), with acceptable error limited to $5 \%(\mathrm{P}=0.05)$. The analysis was separate for site and year due to significant interactions.

\section{RESULTS}

Fallow management treatment effects on soil and tissue $N$, nodulation and Carbon. Inorganic $\mathrm{N}$ was more following dolichos as compared to the weedy fallow (Table 1). However, inorganic $\mathrm{N}$ did not differ for crop fallows except in 1998 at
Rongai where $\mathrm{N}$ was more following dolichos. During the short rains season, the weedy fallow generally produced more biomass than dolichos, garden pea and chickpea (Table 2), with soybean, field bean and maize producing intermediate amounts. $\mathrm{N}$ concentration for weeds was not less than that for legume crops except dolichos at Njoro but generally less compared to all other fallow treatments at Rongai (Table 3). Garden pea and dolichos residues had the highest $\mathrm{N}$ concentration, while soybean had a lower percent $\mathrm{N}$ than other legumes. The $\mathrm{C}: \mathrm{N}$ ratios were consistently higher for weeds and maize than for legumes but were similar amongst all legume crops at both Rongai and Njoro. In 1997/98, nodulation was best for garden peas and field bean, intermediate for soybean and dolichos and poor for chickpea (Table 3). Nodulation was extremely poor in $1999 / 2000$ probably because no inoculation was done and also due to severe water deficits that year; no nodules were found on chickpea, field bean and garden pea.

Fallow management effects on subsequent maize crop. Maize biomass was more following dolichos than for continuous maize and weedy fallow in all cases except for Rongai in 1999 (Table 5). While maize biomass was more following dolichos in two of four cases the other legumes and weedy fallow had less but similar influence. Maize leaf area index (LAI) was more

TABLE 1. Effect of fallow management treatments on soil inorganic- $\mathrm{N}$ at eight weeks after residue incorporation and four weeks after sowing maize

Soil inorganic- $\mathrm{N}\left(\mu \mathrm{g} \mathrm{N} \mathrm{g}^{-1}\right)$

\begin{tabular}{|c|c|c|c|c|c|c|}
\hline \multirow[b]{2}{*}{ Fallow } & \multicolumn{2}{|c|}{ Njoro (1999) } & \multicolumn{2}{|c|}{ Rongai (1998) } & \multicolumn{2}{|c|}{ Rongai (1999) } \\
\hline & $0-15 \mathrm{~cm}$ & $15-30 \mathrm{~cm}$ & $0.15 \mathrm{~cm}$ & $15-30 \mathrm{~cm}$ & $0.15 \mathrm{~cm}$ & $15-30 \mathrm{~cm}$ \\
\hline \multicolumn{7}{|l|}{ treatments } \\
\hline $\begin{array}{l}\text { Chickpea } \\
\text { Field bean } \\
\text { Soybean } \\
\text { Garden pea } \\
\text { Dolichos } \\
\text { Maize } \\
\text { Weedy fallow }\end{array}$ & $\begin{array}{l}32.5^{\mathrm{a}^{\star}} \\
34.8^{\mathrm{a}} \\
37.5^{\mathrm{a}} \\
32.6^{\mathrm{a}} \\
38.2^{\mathrm{a}} \\
40.2^{\mathrm{a}} \\
33.2^{\mathrm{a}}\end{array}$ & $\begin{array}{l}26.9^{a b} \\
.27 .6^{a b} \\
33.4^{a} \\
28.9^{a b} \\
32.9^{a} \\
30.5^{a b} \\
22.9^{b}\end{array}$ & $\begin{array}{l}8.9^{\mathrm{b}} \\
7.2^{\mathrm{b}} \\
9.0^{\mathrm{b}} \\
8.8^{\mathrm{b}} \\
13.9^{\mathrm{a}} \\
7.0^{\mathrm{b}} \\
9.1^{\mathrm{b}}\end{array}$ & $\begin{array}{l}9.5^{\mathrm{b}} \\
10.6^{\mathrm{b}} \\
8.6^{\mathrm{b}} \\
7.3^{\mathrm{b}} \\
15.5^{\mathrm{a}} \\
9.4^{\mathrm{b}} \\
10.0^{\mathrm{b}}\end{array}$ & $\begin{array}{l}39.0^{a b} \\
37.6^{a b} \\
30.6^{a b} \\
37.7^{a b} \\
44.2^{a} \\
36.0^{a b} \\
27.6^{b}\end{array}$ & $\begin{array}{l}25.3^{a b} \\
33.2^{a} \\
26.6^{a b} \\
32.3^{a} \\
36.1^{a} \\
28.3^{a b} \\
19.3^{b}\end{array}$ \\
\hline
\end{tabular}

"Means followed by the same letter in the same column are not significantly different as per LSD test $(\alpha=0.05)$ 
TABLE 2. Above-ground biomass production $\left(\mathrm{Mg} \mathrm{ha}^{-1}\right)$ by the fallow management species during the 1997/98, $1998 / 99$ and 1999/2000 short-rains cropping season in Njoro and Rongai

\begin{tabular}{|c|c|c|c|c|c|c|c|c|}
\hline \multirow{3}{*}{$\begin{array}{l}\text { Fallow } \\
\text { treatments }\end{array}$} & \multicolumn{8}{|c|}{ Above-ground biomass ( $\mathrm{Mg} \mathrm{ha}^{-1}$ ) } \\
\hline & \multicolumn{4}{|c|}{ Njoro } & \multicolumn{4}{|c|}{ Rongai } \\
\hline & $1997 / 98$ & $1998 / 99$ & $1999 / 00$ & $\begin{array}{l}\text { Average } \\
\text { (Njoro) }\end{array}$ & $1997 / 98$ & $1998 / 99$ & $1999 / 00$ & $\begin{array}{c}\text { Average } \\
\text { (Rongai) }\end{array}$ \\
\hline Chickpea & $2.11^{\mathrm{cd}}$ & $1.40^{\mathrm{b}}$ & $1.47^{b c}$ & 1.66 & $1.10^{C}$ & $0.96^{a}$ & $0.46^{\mathrm{b}}$ & 0.84 \\
\hline Field bean & $3.63^{a b}$ & $1.88^{\mathrm{a}}$ & $1.08^{C}$ & 2.20 & $2.83^{a b}$ & $0.52^{\mathrm{a}}$ & $0.45^{\mathrm{b}}$ & $\begin{array}{l}0.24 \\
1.27\end{array}$ \\
\hline Soybean & $2.98^{\mathrm{bc}}$ & $2.22^{\mathrm{a}}$ & $1.56^{\mathrm{bc}}$ & 2.25 & $1.84^{\mathrm{bc}}$ & $1.10^{a}$ & $0.69^{\mathrm{a}}$ & 1.21 \\
\hline Garden pea & $1.36^{d}$ & $0.92^{\mathrm{cd}}$ & $0.99^{C}$ & 1.09 & $2.05^{b c}$ & $*$ & $0.35^{\mathrm{b}}$ & 1.20 \\
\hline Dolichos & $1.44^{\mathrm{d}}$ & $0.57^{d}$ & $0.83^{C}$ & 0.95 & $1.19^{\mathrm{C}}$ & $0.50^{a}$ & $0.32^{b}$ & 0.67 \\
\hline Maize & $4.64^{a}$ & $1.11^{b c}$ & $2.40^{b}$ & 2.72 & $2.14^{b c}$ & $1.72^{\mathrm{a}}$ & $0.49^{a b}$ & 1.45 \\
\hline Weedy fallow & $4.58^{a}$ & $0.71^{c d}$ & $4.08^{a}$ & 3.12 & $3.68^{a}$ & $0.48^{a}$ & $0.51^{a b}$ & 1.56 \\
\hline
\end{tabular}

Means followed by the same letter in the same column are not significantly different as per LSD test $(\alpha=0.05)$ "Biomass missing due to crop damage by Guinea fowls

TABLE 3. Tissue N, C/N ratio and nodules in fallow species at R3 at Rongai and Njoro, 1997/1998

\begin{tabular}{|c|c|c|c|c|c|c|c|c|}
\hline \multirow[t]{2}{*}{ Fallow } & \multicolumn{4}{|c|}{ Njoro } & \multicolumn{4}{|c|}{ Rongai } \\
\hline & $\% \mathrm{~N}$ & $\begin{array}{c}\mathrm{C} / \mathrm{N} \\
\text { (Ratio) }\end{array}$ & $\begin{array}{l}\text { Nodules } \\
\text { (No/plant) }\end{array}$ & $\begin{array}{l}\text { Nodules } \\
\text { (gms/plant) }\end{array}$ & $\% \mathrm{~N}$ & $\begin{array}{c}\mathrm{C} / \mathrm{N} \\
\text { (Ratio) }\end{array}$ & $\begin{array}{l}\text { Nodules } \\
\text { (No/plant) }\end{array}$ & $\begin{array}{l}\text { Nodules } \\
\text { (gms/plant) }\end{array}$ \\
\hline Chickpea & $2.2 a b c$ & $11.5 \mathrm{bc}$ & $1.0 \mathrm{c}$ & $0.0 \mathrm{~b}$ & $2.0^{b}$ & $12.9^{b}$ & $0.5 \mathrm{c}$ & $0.0 a$ \\
\hline Field bean & $1.8 a b c$ & $12.2 \mathrm{bc}$ & $25.6 b$ & $0.1 b$ & $2.0^{\mathrm{b}}$ & $14.1^{b}$ & $10.7 a$ & $0.4 a$ \\
\hline Sovbean & $0.9 c$ & $15.8 b$ & $17.2 \mathrm{bc}$ & $0.3 a$ & $1.8^{b}$ & $14.7^{b}$ & $3.4 \mathrm{bc}$ & $0.1 a$ \\
\hline Garden pea & $2.3 a b$ & $11.8 b c$ & $64.1 a$ & $0.1 b$ & $3.8^{\mathrm{a}}$ & $11.9^{b}$ & $11.6 a$ & $0.1 a$ \\
\hline Dolichos & $2.8 a$ & $9.0 \mathrm{bc}$ & $13.7 \mathrm{bc}$ & $0.4 a$ & $3.4^{a}$ & $12.3^{b}$ & $6.9 a b$ & $0.1 a$ \\
\hline Maize & $2.0 a b c$ & $15.3 b$ & - & - & $1.8^{b}$ & $14.7^{b}$ & - & - \\
\hline Weedy fallow & $1.4 \mathrm{bc}$ & $21.1 \mathrm{a}$ & - & - & $0.9^{c}$ & $21.7^{a}$ & - & - \\
\hline
\end{tabular}

Means followed by the same letter in the same column are not significantly different as per LSD test $(\alpha=0.05)$

TABLE 4. Effect of fallow management treatments on maize dry weight at $V 6$ growth stage in two locations

\begin{tabular}{|c|c|c|c|c|c|c|}
\hline \multirow[t]{3}{*}{ Fallow treatments } & \multicolumn{3}{|c|}{ Njoro } & \multicolumn{3}{|c|}{ Rongai } \\
\hline & \multicolumn{3}{|c|}{ DM yield $\left(\mathrm{Mg} \mathrm{ha}^{-1}\right)$} & \multicolumn{3}{|c|}{$\mathrm{DM}$ yield $\left(\mathrm{Mg} \mathrm{ha}^{-1}\right)$} \\
\hline & 1998 & 1999 & Mean & 1998 & 1999 & Mean \\
\hline Chickpea & $0.75^{a b}$ & $0.49^{a b}$ & 0.62 & $0.29^{b}$ & $0.42^{a}$ & 0.36 \\
\hline Field bean & $0.86^{a b}$ & $0.42^{\mathrm{ab}}$ & 0.64 & $0.24^{b}$ & $0.42^{\mathrm{a}}$ & 0.33 \\
\hline Soybean & $1.06^{\mathrm{ab}}$ & $0.33^{b}$ & 0.70 & $0.27^{b}$ & $0.28^{\mathrm{a}}$ & 0.28 \\
\hline Garden pea & $0.93^{a b}$ & $0.33^{b}$ & 0.63 & $0.16^{b}$ & $0.32^{a}$ & 0.24 \\
\hline Dolichos & $1.20^{\mathrm{a}}$ & $0.68^{a}$ & 0.94 & $0.58^{\mathrm{a}}$ & $0.46^{a}$ & 0.52 \\
\hline Maize & $0.49^{b}$ & $0.35^{b}$ & 0.42 & $0.11^{b}$ & $0.35^{a}$ & 0.23 \\
\hline Weedy fallow & $0.57^{a b}$ & $0.20^{\mathrm{b}}$ & 0.39 & $0.19^{b}$ & $0.30^{\mathrm{a}}$ & 0.25 \\
\hline
\end{tabular}

Means followed by the same letter in the column are not significantly different as per LSD test $(\alpha=0.05)$ 
following chickpea, field bean, soybean and dolichos as compared to maize following maize at both locations, while LAI was not increased by weedy fallow. Generally, highest LAI values were associated with dolichos during both the V9 and R2 growth stages (Tables 5 and 6). Maize LAI did not increase with $\mathrm{N}$ rate at the V9 stage in both locations, however, high $\mathbf{N}$ supply resulted in large increases in maize biomass only at the R2 growth stage in Rongai particularly following dolichos. In general biomass yield was almost twice as large at Njoro when compared to Rongai.

Maize grain yield and yield components. Maize grain yield averaged 4.89 and $3.56 \mathrm{Mg} \mathrm{ha}^{-1}$ in 1998 and 1999, respectively (Table 7a and b) and varied with treatment only in 1998. During that year, maize yield following dolichos was more

TABLE 5. Influence of fallow management species and $\mathrm{N}$ fertilizer application on leaf area index (LAI) at V9 growth stage in maize during 1998 cropping season

\begin{tabular}{|c|c|c|c|c|c|c|c|c|}
\hline \multirow{4}{*}{$\begin{array}{l}\text { Fallow } \\
\text { treatment }\end{array}$} & \multicolumn{8}{|c|}{ Leaf area index (LAI) at V9 } \\
\hline & \multicolumn{4}{|c|}{ Njoro } & \multicolumn{4}{|c|}{ Rongai } \\
\hline & \multicolumn{3}{|c|}{ Nitrogen levels $\left(\mathrm{kg} \mathrm{ha}^{-1}\right)$} & \multirow{2}{*}{$\begin{array}{l}\text { Fallow } \\
\text { species } \\
\text { means }\end{array}$} & \multicolumn{3}{|c|}{ Nitrogen levels ( $\mathrm{kg} \mathrm{ha}^{-1}$ ) } & \multirow{2}{*}{$\begin{array}{l}\text { Fallow } \\
\text { species } \\
\text { means }\end{array}$} \\
\hline & 0 & 30 & 60 & & 0 & 30 & 60 & \\
\hline Chickpea & 1.64 & 1.30 & 1.04 & $1.33^{\mathrm{a}}$ & 1.31 & 0.87 & 1.54 & $1.24^{b}$ \\
\hline Field bean & 1.95 & 1.20 & 1.29 & $1.48^{\mathrm{a}}$ & 0.98 & 1.19 & 1.34 & $1.17^{b}$ \\
\hline Soybean & 1.31 & 1.80 & 1.56 & $1.56^{\mathrm{a}}$ & 1.18 & 1.37 & 1.05 & $1.20^{\mathrm{b}}$ \\
\hline Garden pea & 1.54 & 1.05 & 1.60 & $1.40^{\mathrm{a}}$ & 1.21 & 0.78 & 1.10 & $1.03^{b c}$ \\
\hline Dolichos & 1.73 & 1.76 & 1.36 & $1.62^{\mathrm{a}}$ & 1.69 & 2.09 & 1.70 & $1.83^{\mathrm{a}}$ \\
\hline Maize & 0.62 & 0.78 & 0.91 & $0.77^{\mathrm{b}}$ & 0.71 & 0.68 & 0.53 & $0.64^{c}$ \\
\hline Weedy fallow & 0.86 & 0.70 & 0.88 & $0.81^{b}$ & 1.00 & 0.96 & 1.10 & $1,02^{b c}$ \\
\hline
\end{tabular}

Fallow species means followed by the same letter in the column are not significantly different as per LSD test $(\alpha=0.05)$

Nitrogen treatment means were not significantly different according to the Duncan means separation procedure $(\alpha=0.05)$

TABLE 6. Effect of fallow management species and $\mathrm{N}$ fertilizer application on maize DM yields at $\mathrm{R} 2$ growth stage in Njoro and Rongai during 1998 cropping season.

\begin{tabular}{|c|c|c|c|c|c|c|c|c|}
\hline \multirow{4}{*}{$\begin{array}{l}\text { Fallow } \\
\text { treatment }\end{array}$} & \multicolumn{8}{|c|}{ Maize dry matter yield at $\mathrm{R} 2\left(\mathrm{Mg} \mathrm{ha}^{-1}\right)$} \\
\hline & \multicolumn{4}{|c|}{ Njoro } & \multicolumn{4}{|c|}{ Rongai } \\
\hline & \multicolumn{3}{|c|}{ Nitrogen levels (kg ha $\left.{ }^{-1}\right)$} & \multirow{2}{*}{$\begin{array}{l}\text { Fallow } \\
\text { species } \\
\text { means }\end{array}$} & \multicolumn{3}{|c|}{ Nitrogen levels $\left(\mathrm{kg} \mathrm{ha}^{-1}\right)$} & \multirow{2}{*}{$\begin{array}{l}\text { Fallow } \\
\text { species } \\
\text { means }\end{array}$} \\
\hline & 0 & 30 & 60 & & 0 & 30 & 60 & \\
\hline Chickpea & 17.99 & 15.07 & 16.64 & $16.57^{\mathrm{ab}}$ & 5.80 & 9.04 & 13.00 & $9.28^{b}$ \\
\hline Field bean & 13.95 & 21.64 & 13.61 & $16.40^{a b}$ & 6.90 & 7.04 & 13.84 & $9.26^{\mathrm{b}}$ \\
\hline Soybean & 19.78 & 21.20 & 14.96 & $18.64^{a b}$ & 5.90 & 7.23 & 11.86 & $8.33^{b}$ \\
\hline Garden pea & 17.91 & 13.30 & 25.63 & $18.95^{a b}$ & 8.72 & 8.11 & 11.35 & $9.39^{b}$ \\
\hline Dolichos & 26.77 & 18.85 & 18.66 & $21.43^{\mathrm{a}}$ & 13.68 & 15.30 & 15.69 & $14.89^{\mathrm{a}}$ \\
\hline Maize & 12.90 & 8.81 & 11.65 & $11.12^{b}$ & 6.25 & 7.79 & 8.08 & $7.37^{b}$ \\
\hline $\begin{array}{l}\text { Weedy fallow } \\
\mathrm{N} \text { means }\end{array}$ & 12.38 & 11.72 & 13.50 & $12.53^{\mathrm{ab}}$ & 7.28 & 7.79 & 9.80 & $8.29^{b}$ \\
\hline$\left(\mathrm{Mg} \mathrm{ha}^{-1}\right)$ & $17.38^{\mathrm{a}}$ & $15.80^{\mathrm{a}}$ & $16.38^{a}$ & & $7.79^{b}$ & $8.90^{a t}$ & $11.95^{a}$ & \\
\hline
\end{tabular}

Fallow treatment means followed by the same letter within a column and nitrogen means within a row are not significantly different as per LSD test $(\alpha=0.05)$ 
than continuous maize and weedy fallow at both sites, but the positive impact of other legumes was less conspicuous.

\section{DISCUSSION}

This study was undertaken primarily to investigate if a rotation of maize with selected grain legumes had the potential of improving maize grain yield through enhanced conditions of nutrient supply, particularly nitrogen. Except during extremely dry conditions that prevailed in 1999 , the results of this study show that maize yields were limited by insufficient supply of nitrogen regardless of location (Table 7). Also, managing fallows with legumes resulted in increases in maize grain yield averaging $6.75 \mathrm{Mg} \mathrm{ha}{ }^{-1}$ compared to $4.90 \mathrm{Mg}$ $\mathrm{ha}^{-1}$ for continuous maize or weedy fallow. This reflects a $39 \%$ gain in yields associated with fallow improvement practice. These results are comparable to others (Bundy et al., 1993; Badaruddin and Meyer, 1994; Horst and Hardter, 1996; Fischler and Wortman, 1999; Kasasa et al., 1999).

Despite the large quantities of residue in the weedy fallow and continuous maize (Table 2), the impact of these fallow management options on maize dry matter accumulation and grain yield in

TABLE 7. Effect of fallow management species and applied $\mathrm{N}$ fertiliser on maize grain yield $\left(\mathrm{Mg} \mathrm{ha}^{-1}\right)$ at Njoro and Rongai in (a) 1998 and (b) 1999 cropping seasons

\begin{tabular}{|c|c|c|c|c|c|c|c|c|}
\hline \multirow{3}{*}{$\begin{array}{l}\text { Fallow } \\
\text { treatment }\end{array}$} & \multicolumn{4}{|c|}{ Njoro } & \multicolumn{4}{|c|}{ Rongai } \\
\hline & \multicolumn{3}{|c|}{ Nitrogen levels $\left(\mathrm{kg} \mathrm{ha}^{-1}\right)$} & \multirow{2}{*}{$\begin{array}{l}\text { Fallow } \\
\text { species } \\
\text { means }\end{array}$} & \multicolumn{3}{|c|}{ Nitrogen levels $\left(\mathrm{kg} \mathrm{ha}^{-1}\right)$} & \multirow{2}{*}{$\begin{array}{l}\text { Fallow } \\
\text { species } \\
\text { means }\end{array}$} \\
\hline & 0 & 30 & 60 & & 0 & 30 & 60 & \\
\hline
\end{tabular}

a) Maize grain yield in $1998\left(\mathrm{Mg} \mathrm{ha}^{-1}\right)$

$\begin{array}{lllllllll}\text { Chickpea } & 5.66 & 7.20 & 8.37 & 7.08^{\mathrm{ab}} & 4.45 & 4.75 & 6.38 & 5.19^{\mathrm{b}} \\ \text { Field bean } & 6.25 & 5.97 & 7.12 & 6.44^{\mathrm{abc}} & 4.05 & 4.39 & 7.19 & 5.21^{\mathrm{b}} \\ \text { Soybean } & 5.84 & 5.88 & 8.38 & 6.70^{\mathrm{ab}} & 4.33 & 5.26 & 5.68 & 5.09^{\mathrm{bc}} \\ \text { Garden pea } & 5.57 & 5.31 & 7.23 & 6.04^{\mathrm{bc}} & 4.28 & 3.59 & 4.50 & 4.12^{\mathrm{bc}} \\ \text { Dolichos } & 6.95 & 7.74 & 7.85 & 7.51^{\mathrm{a}} & 6.32 & 6.96 & 7.43 & 6.90^{\mathrm{a}} \\ \text { Maize } & 4.28 & 5.33 & 6.18 & 5.26^{\mathrm{cd}} & 3.49 & 2.27 & 4.55 & 3.60^{\mathrm{c}} \\ \text { Weedy fallow } & \mathbf{5 . 0 5} & 2.79 & \mathbf{5 . 7 5} & 4.53^{\mathrm{d}} & 3.33 & 4.49 & 4.48 & 4.10^{\mathrm{bc}}\end{array}$

$\mathrm{N}$ means

$\left(\mathrm{Mg} \mathrm{ha}^{-1}\right)$

$5.66^{b} \quad 5.74^{b} \quad 7.27^{a}$

$4.32^{\mathrm{b}} \quad 4.60^{\mathrm{b}} \quad 5.74^{\mathrm{a}}$

b) Maize grain yield in $1999\left(\mathrm{Mg} \mathrm{ha}^{-1}\right)$

\begin{tabular}{|c|c|c|c|c|c|c|c|c|}
\hline Chickpea & 2.17 & 2.11 & 2.18 & $2.15^{\mathrm{a}}$ & 2.73 & 4.00 & 4.22 & $3.65^{a}$ \\
\hline Field bean & 1.78 & 2.59 & 3.13 & $2.50^{\mathrm{a}}$ & 3.79 & 2.76 & 4.07 & $3.64^{\mathrm{a}}$ \\
\hline Soybean & 1.99 & 2.39 & 2.08 & $2.15^{a}$ & 3.98 & 3.57 & 3.55 & $3.66^{\mathrm{a}}$ \\
\hline Garden pea & 2.58 & 2.13 & 2.93 & $2.68^{a}$ & 3.16 & 1.96 & 5.01 & $3.38^{a}$ \\
\hline Dolichos & 2.29 & 2.32 & 3.00 & $2.57^{\mathrm{a}}$ & 3.10 & 3.12 & 5.07 & $3.76^{\mathrm{a}}$ \\
\hline Maize & 2.86 & 1.21 & 2.86 & $2.31^{a}$ & 3.23 & 2.83 & 3.95 & $3.34^{\mathrm{a}}$ \\
\hline Weedy fallow & 2.34 & 2.49 & 2.02 & $2.28^{a}$ & 2.91 & 3.41 & 4.22 & $3.51^{\mathrm{a}}$ \\
\hline $\begin{array}{l}\mathrm{N} \text { means } \\
\left(\mathrm{Mg} \mathrm{ha}^{-1}\right)\end{array}$ & $2.27^{a}$ & $2.18^{a}$ & $2.60^{\mathrm{a}}$ & & $3.23^{b}$ & $3.11^{b}$ & $4.30^{\mathrm{a}}$ & \\
\hline
\end{tabular}

Fallow species means followed by the same letter in the same column are not significantly different as per LSD test $(\alpha=0.05)$

Nitrogen treatment means followed by the same letter in the row are not significantly different according to the LSD test $(\alpha=0.05)$ 
the subsequent season was negligible (Tables 6 and 7). This is not suprising because the critical enhancing feature of fallow species appears to be residue quality as defined by levels of tissue- $\mathrm{N}$ and $\mathrm{C}: \mathrm{N}$ ratio rather than biomass quantity per se. Thus, the improved maize yields associated with legumes, particularly dolichos, is as a result of high residue quality. The extend to which residue quality can impact on crop performance in tropical environments has been reported in several stụdies (Tian et al., 1994).

Whilst the benefits of improved fallow are largely attributable to improved $\mathrm{N}$ supply, and low $\mathrm{C}: \mathrm{N}$ ratio characteristics of the legume (Fox et al., 1990; Maroko et al., 1998; Ojiem et al., 1998), other factors which this study did not quantify, may have played a part. These include improvement in soil physical and chemical properties such as bulk density, water holding capacity, and improved cation exchange capacities (McVay et al., 1989). Maize may also be self incompatible (Yakie and Cruse, 1984) since maize residue often retards growth of seedling maize crop due to the presence of phytotoxins.

A second major observation from this study is that dolichos, in contrast to other legumes selected for fallow improvement, consistently induced faster canopy development (Table 5), higher biomass accumulation (Table 6) and more grain yield (Table 7) in the subsequent maize crop. The reasons that support this apparent superiority of doilchos may be several and complex. Dolichos sets seed late and partitions comparatively less dry matter to reproductive tissues (data not shown) and hence it has a low nitrogen harvest index (NHI). By the time legume residue was incorporated, dolichos had just poded but not seeded and hence most of the $\mathrm{N}$ accumulated was still in vegetative tissue. Also, available evidence suggests that most grain legumes typically remove more $\mathrm{N}$ from the soil than they leave behind inspite of capacities for atmospheric $\mathrm{N}_{2}$ fixation (Table 3) and this is due to their high NHI (Giller and Wilson, 1991; Toomsan et al., 1995).

Both the dry matter accumulation and grain yield (Tables 6 and 7) suggest that Njoro was a more favourable environment for maize growth than Rongai. This is probably because it is cooler in Njoro; the cool temperatures allowing for a longer period of post anthesis DM accumulation and grain development (Forbes and Watson, 1992). Njoro had also a lot more rain; the total precipitation during the long rains was 560 and $420 \mathrm{~mm}$ in 1998 at Njoro and Rongai, respectively, as contrasted with 366 and $264 \mathrm{~mm}$ at the two sites in 1999. In addition, baseline soil analysis data suggest that Njoro has more conducive soil environment, with an average $0.25 \%$ total N, 20 ppm $\mathrm{P}$ and $4.63 \%$ organic matter compared to $0.08 \% \mathrm{~N}, 0.22 \mathrm{ppm} \mathrm{P}$ and $2.47 \%$ organic matter at Rongai (data not shown). The grain yields although well above average farm levels at Njoro in 1998 (Table 7), did not march the large accumulation of DM by the maize crop that year (Table 6). This response is partly attributable to the dry conditions that prevailed during anthesis at this location, thus prolonging the anthesissilking interval (ASI) beyond 10 days and inducing kernel abortion. This suggests that the reproductive tissue did not develop a strong enough sink to attract all the available photoassimilate from vegetative structures (Lorens et al., 1987).

In conclusion, it is evident from this study that smallholder cropping enterprises could be improved if farmers rotate maize with grain legumes, particularly dolichos as a source of $\mathrm{N}$ on the proviso that the legume residue is left in the field and incorporated. It is also noted that the biological and economic buffering offered by multiple species in sequential cropping affords stability of harvest and income over time space against risk of crop failure. There is need for further study to determine the precise synchrony between the time of legume residue incorporation, peak release and crop demand, along the lines suggested by Yamoah et al. (1986)

\section{ACKNOWLEDGEMENTS}

This work was supported through a research grant by The Rockefeller Foundation and research facilities provided by Egerton University, Kenya. The study was part of post graduate work that was submitted to the Graduate School at the University by the first author.

\section{REFERENCES}

Badaruddin, M. and Meyer, D.W. 1994. Grain legume effects on soil $\mathrm{N}$, grain yield and $\mathrm{N}$ 
nutrition of wheat. Crop Science 34: 13041309.

Bundy, L.G., Andraski, T.W. and Wolkowski, R.P. 1993. Nitrogen credits in soybean-corn crop sequences on three soils. Agronomy Journal 83:1061-1067.

Fischler, M. and Wortmann, C.S. 1999. Green manure for maize-bean systems in eastern Uganda: Agronomic performance and farmers' perceptions. Agroforestry Systems 47:123-138.

Forbes, J.C. and Watson, R.D. 1992. Plants in Agriculture. University Press, Cambridge.pp. 264-268.

Fox, R.H., Myers, R.J.K. and Vallis, I. 1990. The nitrogen mineralization rate of legume residues in soil as influenced by their polyphenol, lignin, and nitrogen content. Plant and Soil 129:251-259.

Giller, K.E. and Wilson, K.J. 1991. Nitrogen Fixation in Tropical Cropping Systems. CAB International, Wallingford.

Guto, S.N. 1997. Effects of chickpea (Cicer arietinum cv. Kaburi) and common beans (Phaseolus vulgaris L. cv. Rose coco) on wheat performance and soil fertility in a legume-wheat cropping 'sequence. MSc Thesis, Egerton University, Njoro, Kenya.

Handayanto, E., Nuraini, Y., Purnomosidi, P., Hanegraaf, M., Agterberg, G., Hassink, J. and van Noordwijk, M. 1992. Decomposition rates of legume residues and $\mathrm{N}$-mineralization in an ultisol in Lampung. AGRIVITA 15:75-86.

Horst, W.J. and Hardter, R. 1994. Rotation of maize with cowpea improves yield and nutrient use of maize compared to maize monocropping in an alfisol in the northern Guinea savanna of Ghana. Plant and Soil 160:171-184.

Jaestzold, R. and Schmidt, H. 1983. Farm management hand book of Kenya. Vol.II/B Central Kenya. Ministry of Agriculture, Kenya in Corporation with German-Agricultural Team (GAT) of German Agency of Technical Co-operation (GTZ).

Kasasa, P., Mpepereki, S., Musiyiwa, K., Makonese, F. and Giller, K.E. 1999. Residual nitrogen benefits of promiscuous soybean to maize under field conditions. African Crop Science Journal 7:375-382.
KARI. 1992. Improve and sustain maize production through adoption of known technologies. Information Bulletin, Kenya Agricultural Research Institute, Nairobi, Kenya.

KARI. 1997. Crop production guidelines for wheat, oil crops and horticulture. National Plant Breeding Research Centre, Njoro, Kenya.

KARI and MIAC. 1993. Strategic planforcereals in Kenya (1993-2013). Kenya Agricultural Research Institute, Nairobi, Kenya.

Kwesiga, F. and Coe, R. 1994. The effect of short rotation Sesbania sesban planted fallows on maize yield. Forest Ecology and Management 64:199-208.

Lorens, G.F., Bennett, J.M. and Loggale, L.B. 1987. Differences in drought resistance between two corn hybrids: component analysis and growth rates. Agronomy Journal 79: 897 912.

Maroko, J.B., Buresh, R.J. and Smithson,. P.C. 1998. Soil nitrogen availability as affected by fallow-maize systems on two soils in Kenya. Biol Fert. 26:229-234.

Marschner, H. 1995 Mineral Nutrition of Higher Plants. Academic Press. pp. 201-228.

McVay, K.A., Radcliffe, D.E. and Hargrove, W.C. 1989. Winter legume effects on soil properties and nitrogen fertiliser requirements. Soil Science Society of America Journal 53:18561862.

Muriuki, E.M. 1998. Report of the ECAMAW Working Group meeting on Soil Fertility issues in maize and wheat based system in Eastern and Central Africa. 15-19 ${ }^{\text {th }}$ November 1998, Mombasa, Kenya.

Norman, J.M. and Campbell, G.S. 1989. Canopy structure. In: Plant Physiological Ecology: Field Methods and Instrumentation. Pearcy, R.W., Ehleringer, J., Mooney, H.A. and Rundell, P.W. (Eds.), pp. 301-326. Chapman and Hall.

Oikeh, S.O., Chude, V.O., Carsky, R.J., Weber, G.K. and Horst, W.J. 1998. Legume rotation in the moist tropical savanna: managing soil nitrogen dynamics and cereal yields in farmers' fields. Experimental Agriculture 34:73-83.

Ojiem, J.O., Ransom, J.K., Odongo, O.M. and Okwuosa, E.A. 1998. Agronomic and 
chemical characterization of potential green manure species in western Kenya. In: Proceedings of the Sixth Eastern and Southern Africa Regional Maize Conference. 21-25 September. CIMMYT, Nairobi.pp. 210-213. Okalebo, J.R., Gathua, K.W. and Woomer, P.L. 1993. Laboratory methods of soil and plant analysis: A working manual. Tropical Soil Biology and Fertility Programme (TSBF). Nairobi, Kenya.

Onim, I.F.M., Mathuva, M., Otieno, K. and Fitzhugh, H.A. 1990. Soil fertility changes and response of maize and beans to green manures of Leucaena, Sesbania and Pigeonpea. Agroforestry Systems 12:197-215.

Onwonga, R.N. 1997. Effect of chickpea incorporation on soil nutrient status and wheat grain yield in a wheat-chickpea rotation. MSc Thesis, Egerton University, Njoro, Kenya.

Palm, C.A. 1995. Contribution of agroforestry trees to nutrient requirements of intercropped plants. Agroforestry System 30:105-124.

Page, A.L., Miller, R.H. and Keeney, D.R. 1982. Methods of soil analysis. Part 2. Chemical and microbiological properties. American Society of Agronomy, USA.

Peoples, M.B., Herridge, D.F. and Ladha, J.K. 1995. Biological nitrogen fixation: An efficient source of nitrogen for sustainable agricultural production. Plant and Soil 174:3-28.

Rheenen, H.A.V., Tullu, A., Mohamed, A.I.S. and Omanga, P. 1991. Growing chickpea in Eastern Africa. International Crops Research Institutefor the Semi-Arid Tropics(ICRISAT). Patancheru, India.

Ritchie, W.S., Hanway, J.J. and Benson, G.O. 1986. How a corn plant develops. Special report No.48. Extension service, Ames, Iowa.
SAS institute. 1996. SAS for windows 6.12. Cary NC 27513 USA.

Steel, R.G.D., Torie, J.H, and Dickey, D.A. 1997 Principles and Practices of Statistics: $a$ biometrical approach. McGrawhill Companies Inc.

Tanner, D.G., Yilma, Z., Zewdie, L. and Gebru, G. 1994. Potential for cereal-based double cropping in Bale region of South Eastern Ethiopia. African Crop Science Journal 2:135143.

Tian, G., Kang, B.T. and Brassard, L. 1994. Mulching effect of plant residue with chemically contrasting composition on maize growth and nutrient accumulation. International institute of Tropical Agriculture (IITA) Research Bulletin 9:7-11.

Toomsan, B., McDough, J.F., Limpnuntana, V.H.A. and Giller, K.E. 1995. Nitrogen fixation by groundnuts and soybean and residual nitrogen benefits to rice in farmers fields in northern Thailand. Plant and Soil 175:45-56.

World Bank. 1998. World Development Indicators. Washington D. C., USA.

Wortmann, C.S., Isabirye, M. and Musa, S. 1994. Crotalaria ochroleuca as a green manure crop in Uganda. African Crop Science Journal 2:55-61.

Yakie, G.A. and Cruse, R.M. 1984. Effects of fresh and decomposing plant residue extracts on corn seedling development. Soil Science Society of America Journal 48:1143-1146.

Yamoah, C.F., Agboola, A.A. and Mulongoy, K. 1986. Decomposition, nitrogen release and weed control by prunings of selected alley cropping shrubs. Agroforestry Systems 4:239246. 